Article

\title{
The Art of Violent Protest and Crime Prevention
}

\author{
John Kerr
}

Department of Social Sciences, University of Roehampton, SW15 5SL London, UK; john.kerr@roehampton.ac.uk

Received: 22 June 2018; Accepted: 2 October 2018; Published: 8 October 2018

check for updates

\begin{abstract}
This article examines violent protest in art museums. There is a long history of art museums being used as sites of protest. As spaces full of meaning, they represent ideal locations for people to try to shape the present and the future. From peaceful demonstrations to terrorist attacks, the current risks of protest to art museums is high. Motivated by ideological, political and social reasons, these protests include those that specifically target art objects within the art museums, as well as others that use the sites as stages on which to protest. This article is based predominantly on secondary sources; however, it also uses empirical research data collected by the author during observation research at art museums in London in March 2017 and July 2017. The article begins by considering why art museums attract so many protests. It argues that as 'sites of persuasion', art museums can be battlegrounds on which people look to shape how society is constructed and perceived. It then examines contemporary and historical case studies in Brazil and the UK to help our understanding of violent protests and the challenges they pose to art museums. Following this, the article proposes that as art museums are important sites of persuasion, there must be more awareness of the threats they face from violent protests in order to shape crime prevention approaches. The article finishes by arguing that although protests can be highly problematic for people involved with art museums, the ongoing appeal of these spaces as sites of protest shows the significance of art museums as important locations of cultural meaning.
\end{abstract}

Keywords: violent protest; art crime; art museums; situational crime prevention; terrorism

\section{Introduction}

The world of art museums has become the world of culture wars.

$$
\text { Sepulveda dos Santos (2003, p. 27). }
$$

Adding to the growing body of academic research and literature that addresses the many varied issues that can constitute art crime, this article examines violent protest in art museums. It uses knowledge from academic fields such as art history, arts administration and museum studies to help understand the threat and to shape crime prevention approaches and their application in art museums. Globally, many art museums currently face a high level of risk from protests that range from peaceful demonstrations to terrorist attacks. Art museums have a long history of being sites of violent protests. People are drawn to these spaces to protest because they are sites of past, present and future meaning and, therefore, they represent ideal locations in which to try to shape the present and the future. Motivated by political, social and ideological reasons, these protests include those that specifically target objects and displays within the art museums, as well as those that use the art museums as stages on which to protest. Rather than the production of art as the protest, the focus of this article is on protests that are the reactions to art or are using art museums as stages on which to protest.

This article is based primarily on secondary sources. However, it also uses empirical research data collected during observation research at art museums in London in March 2017 and July 2017. The article begins by analysing why art museums attract violent protests. It then examines 
two contemporary and historical case studies in Brazil and the UK, focusing in particular on the differing motivations that drove the protests in both countries and the risks and challenges these protests posed to the art museums. The article proposes that, as 'sites of persuasion', art museums can be battlegrounds on which people look to shape how society is constructed and perceived (Dubin 2006, p. 478). Owing to this, those managing the spaces must have awareness of the threats they face from violent protests and be prepared to respond quickly. Typical situational crime prevention approaches can be too limited when dealing with the threat of violent protest and there needs to be more awareness in crime prevention analyses of the meaning that these sites can have for people. Lastly, the article claims that the ongoing appeal of these spaces as sites of protest signifies the importance of art museums as spaces of cultural meaning in societies. If art museums are no longer seen as spaces for conversation, persuasion, contestation and protest (however violent these protests might be), then they have lost their meaning and serve little purpose other than to be venues selling reproductions of famous images and refreshments.

This article uses the broad definition of 'art museums' to include art galleries and museums in which art is displayed. The term art museums is more common in the US where there is less of the understood distinction between the 'art gallery' and 'museum' that can exist in the UK (Duncan 1995; Kerr 2015). The terms 'terrorism' and 'terrorist' are employed with recognition of the controversies about how they can be used (Newman and Clarke 2007; Soyinka 2004; Young 2007). This author fully acknowledges that states and those with dominant power can be terrorists and enact terrorism. The article uses Taylor and Van Dyke's definition of protest as 'sites of contestation in which bodies, symbols, identities, practices, and discourses are used to pursue or prevent changes in institutionalised power relations' (Taylor and Van Dyke 2004, p. 268). The term 'violent protest' is used with the implication that the threat (or actual use) of force to people or property exists in the act.

\section{Art as Power and Politics}

The artist Wolgang Tillmans has said that art has the right not to have a use (Tillmans 2017). In addition, art does not have to be symbolic or be an ideological, political or social instrument. However, art often does have symbolic power and is intentionally produced by artists to be an instrument in some way (Bessette 2016; Bourdieu 1996). It is also used as an instrument by a panoply of other people, from curators and owners, to politicians. One way this can occur is for art to have a use or meaning placed on it by others (Becker 1982). For instance, Berthe Morisot's French Impressionist painting titled Jour d'été (Summer's Day), which depicted two women in a boat on a French lake, became an Irish nationalist symbol because of ongoing ownership disputes between Ireland and the UK (Kerr 2018).

In 1972, John Berger wrote that 'the entire art of the past has now become a political issue' (Berger 1972, p. 33). He was arguing this because he believed that a people or class who can 'situate itself in history' is freer than one disconnected from their past, who are more constrained by choice and ability to act as a people or class. Building on Walter Benjamin's work, he also argued that the reproduction of image had then freed art and the language of images had become paramount. What was then important was who used that language and why (Berger 1972). However, while the language of images remains paramount, art museums have retained their significance and have arguably become even more important than they were previously. This is shown in the growth and scale of cultural economies in many countries, evidenced by the high visitor numbers to art museums in cities across the globe, and the soft power for which art museums are used by governments, corporations and institutions nationally and internationally (Art Newspaper 2017; Nisbett 2016; Sylvester 2009). Furthermore, the original production of the image, for example an original painting, has often increased in importance owing to the reproduction of its image as well as other factors such as thefts (e.g., Da Vinci's Mona Lisa and Munch's Scream paintings).

Art museums' significance, though, is more complex than it might have been before. For example, Berger (1972) emphasised that art museums had been used to reinforce authority, especially the 
authority of those in power. Similarly, Bourdieu and Darbel (1969, p. 165) argued that 'art museums give some a feeling of cultural ownership and belonging while they make others feel inferior and excluded'. Duncan (1995) agreed but, importantly, highlighted how this view was too limited. Other writers have also criticized Bourdieu's rigid view of museums and the arts (Barrett 2011). Duncan (1995) underlined the symbolic importance of art museums and argued strongly that they should be seen as 'a species of ritual space' despite being locations of secular knowledge and proponents of secular truths (Duncan 1995, pp. 8, 107). She argued: 'It is, in my view, precisely the complexity of the art museum-its existence as a profoundly symbolic cultural object as well as an ideological, political and social instrument-that makes the notion of the museums as ritual so attractive' (Duncan 1995, p. 5). For her, there are two ritual features: first, visitors can expose themselves to a type of experience different from their day-to-day lives; and second, the performance of these visitors in the 'script' or 'scenario' that is shaped by the configuration of the museum settings (Duncan 1995, p. 20). This performative aspect of museums and other public spaces is often disregarded (Barrett 2011).

Owing to their symbolic importance and use as highly political, social and ideological instruments, art museums have been, and remain, extremely important sites to control. Duncan (1995) argues this is because:

To control a museum means precisely to control the representation of a community and its highest values and truths. It is also the power to define the relative standing of individuals within that community. Those who are best prepared to perform its ritual-those who are most able to respond to it various cues-are also those whose identities (social, secular, racial, etc.) the museum ritual most fully confirms. It is precisely for this reason that museums and museum practices can become objects of fierce struggle and impassioned debate. What we see and do not see in art museums-and on what terms by whose authority we do or do not see it-is closely linked to larger questions about who constitutes the community and who defines its identity. (Duncan 1995, pp. 8, 9)

The power, the struggle and debate described by Duncan (1995) reinforce a key point for this article: that while art museums and the objects within them still, to an extent, convey and reinforce ideologies and shape how society sees itself and is viewed by others, many art museums are 'sites of contestations' that have provided, and continue to provide, 'battlegrounds' to challenge dominant discourses (Barrett 2011, p. 89; Calirman 2012; Dubin 2006, p. 481). The 'battlegrounds' are parts of 'culture wars' (Hunter 1991; Sepulveda dos Santos 2003). Hunter (1991) articulates these wars as fights between the 'impulse towards orthodoxy' from 'the impulse toward progressivism' (Hunter, 1991, pp. 42, 43). Harris (1995) highlights how in the US, a major shift happened in the 1960s in which museums became spaces where knowledge was contested or disputed. Dubin (2006) writes that the 'culture wars' in the US have been especially evident in certain locations, particularly museums, heritage sites and monuments. He argues that memory and meaning are generated at these 'sites of persuasion', and that the conflict and negotiation can shape the visions of the future (Dubin 2006, p. 478). In a move from 'critique to strategy', the contestations involved can take the form of protests (Liberate 2015, p. 83).

Globally, protests at art museums have taken many forms. Artists are often at the forefront of the protests. Indeed, the artist Adam Chodzko argues: 'All art is a form of protest' (Frieze 2017a). Although other artists disagree with his assertion, the power of art and the platforms on which it is shown can clearly have power. The artist Neha Choksi argues that for tens of thousands of years, art has allowed people to exclaim: 'I am here. I am making a mark. I am saying I exist. I matter. We matter. We matter together' (Frieze 2017a). This is the power of art. Ranciere (2010) highlights the paradoxes of political art, in that art can change how people view the visible and its self-evidence, but that art can also become a parody of what it can achieve. He writes that, while for Deleuze, 'art is politics', there is an unresolved tension between art being 'itself and beyond itself' in the sense of being art and also political protest. He argues that this tension must be upheld (Ranciere 2010, pp. 172, 183). While this tension exists, and art can indeed be a form of protest and 
statement, this article shows how reactions to art also form a significant type of protest, and that often, these protests can be violent. It is on these violent protests that this article focuses, rather than on the actual art produced as protest or artists' protest activities. While the violent protests in this article were clearly performances that sought wide audiences, they were not actually intended to be art in themselves. In short, they were using the art and art museums for the protest rather than creating art as the protest. This is not always easy to separate, though, because people such as The Tactical Media group Critical Art Ensemble (CAE), Liberate Tate and feminist activist artists the Guerrilla Girls illustrate in their protest art (The Guerrilla Girls 2018; Liberate 2015; Sholette 2010).

Recent examples of violent protest at cultural locations include the destruction of cultural sites and artefacts by ISIS, especially in Syria and Northern Iraq, which the Director General of UNESCO labelled 'cultural cleansing' (UNESCO 2017). This also included the performance of destruction as many objects were actually sold in international art markets (Brodie 2015; Rutelli 2016). Another example is the destruction of heritage in Timbuktu and Gao in Mali in 2013 and the killing of 24 people during a siege of a museum in Tunisia in 2015 (Abungu 2016). These cases underline that while art museums can be sites of persuasion, violence can play a large role in this 'persuasion' through 'symbolic politics' (Francioni and Lenzerini 2006, p. 32). For instance, Rutelli (2016) highlights a quote from one of the perpetrators of the damage inflicted on the Mosul Museum in Northern Iraq: 'Let's go destroy the British Museum!' (Rutelli 2016, p. 145). Although it might have been rhetoric, it showed an awareness by ISIS of the significance of cultural locations such as the British Museum in London. This point is supported further by the recent conviction of Safaa Boular, a member of an all-female ISIS cell, who planned an attack on the British Museum in 2017 in what would have been an extremely violent form of protest (BBC 2018).

In this article, the lens of investigation is pointed towards two specific case studies, as they provide useful examples through which to consider why and how violent protests can happen. The first case study comes from Brazil in 2017 and underlines how museums can be used as sites of persuasion to challenge a popular progressive discourse promulgating a secular, free, open version of society in order to try to impose a populistic, conservative discourse as the dominant narrative in Brazil's polarised society. The actors in the protests were very aware of the significance of the locations and understood that to control art museums would enable them to manipulate how the 'community' is represented and to shape this community's 'truths' and 'values' (Duncan 1995). The extent of the counter protests that occurred also reinforces how people understood the importance of the locations. The second case study comes from the UK in 1913/4 and shows how actors in the protests can use art museums as 'sites of persuasion' to challenge dominant discourses and 'community's' 'truths' and 'values'. In contrast to the first case study, the protesters in the UK in 1913/4 were proposing a freer and more equal society. Their goal was to achieve the right for women to vote. The fact that the case study which was fighting for a progressive future occurred more than 100 years ago, and the one trying to curtail freedom happened in 2017, underlines how important art museums have been within the contestation of power, both in the past and present, and how they could be in the future. The historical case study remains a very relevant example of how and why art museums can be targeted, and that some security measures are inappropriate and serve to further the cause behind the violent protest.

\section{Data Sources}

This article is predominately based on secondary sources. However, data collected by the author in 'complete observer' (Burgess 2000) observation research at cultural locations in London in 2017 was also used in the article to provide supplementary information for Section 5. Although the extent of the empirical research was limited, it provided useful data.

This empirical research consisted of visiting 15 sites in London between 1-18 March 2017 and between 3-11 July 2017. The sites were: 7 large national art museums (public sector), 3 private sector art museums, 1 medium sized public sector art museum, 1 small public sector art museum, 1 cathedral, 1 church, 1 large library. Many sites were visited on multiple occasions. For example, the 
author visited two large national art museums twice in March and visited both again once in July. Although the number of locations was limited and the purposive sampling employed in the choices of locations was shaped by the author's subjectivity, these sites included the largest (measured by visitor numbers) national art museums in London. These museums all have very significant collections. Previous research on art museums has highlighted that the temporal dimension is one that should be considered (Kerr 2015). This dimension was particularly important in this empirical research owing to the series of terrorist attacks that took place in London and Manchester between March and June 2017. The purpose of the visits was to note the visible security measures employed at the sites. Following an approach employed by the author when conducting previous research on the same sites (Kerr 2014), the field notes taken in the visits in March and July were varied and recorded aspects potentially related to security, including features that, at first, might not appear wholly relevant. However, in the visits in July, while this approach was still utilized, some specific aspects were the main focus. These included whether bag checks were being conducted at entrances (and how they were being undertaken), the number of entry points, the number of security personnel at the entrances and inside, and the performance of the security (e.g., security personnel wearing high visibility vests). For ethical issues, the names of the locations are withheld.

\section{Case Studies of Violent Protest}

\subsection{Brazil Case Study}

Brazil is an ideal case study because of the history of cultural production used to contest power in the country (Calirman 2012; Pelegrini 2015). Art museums in Brazil have been, and continue to be, sites of persuasion where political issues are contested. Since the 1960s, culture in Brazil has appeared at times to be more political than governments and the legal system. This is because cultural producers have a history in Brazil of addressing issues that political and legal areas prefer not to. For instance, Brazil can appear from political and legal domains to lack a culture of memory of the 1964-1985 military dictatorship (Schneider and Atencio 2016). However, cultural production has a lengthy record of addressing the dictatorship and its aftermath. Highlighting the historical significance of culture in Brazil, it is important to emphasise that during the dictatorship, many cultural producers across a range of media (e.g., music, art, theatre and cinema) used innovative approaches to avoid the censors, particularly after Ato Institucional \#5 (Institutional Act \#5) in 1968. This Act suspended civil and political rights and sanctioned torture against the regime's political opponents (Calirman 2012; Pelegrini 2015).

The actions of many leading cultural figures from music, art, theatre and cinema who were imprisoned and/or exiled during the military dictatorship showed the importance of cultural production in addressing and tackling the universalisations of particular values in Brazil (Calirman 2012). Concerning addressing the dictatorship after it had ended, the arena of cultural production could engage with the plurality of memories and create discussion (Schneider and Atencio 2016). From the 1980s to the 2000s, there was an increase in democratic rights and representations of Brazil within the country. Sepulveda dos Santos (2003) highlights the role of art museums in this significant growth. In light of the part that art museums can play in reproducing social order and the justified criticisms that they can promote universalisations of particular values (Berger 1972; Bourdieu and Darbel 1969; Sepulveda dos Santos 2003), it is significant that, as locations of identity building, art museums were not forming a single collective identity but, instead, were offering the possibility that cultural ownership could be shared. Identity could be explored in these spaces rather than imposed (Sepulveda dos Santos 2003). A useful example are African-Brazilian museums. Sepulveda dos Santos (2005) argued that: 'The new representations of blackness in African-Brazilian museums, therefore, may be understood as part of the enlargement of democratic rights and, certainly, as responsible for the construction of new narratives about the nation and their people' (Sepulveda dos Santos 2005, p. 61). Although hard to measure the impact of these museums on 
helping African-Brazilians situate themselves in the Brazilian 'community', it is important that this shift did occur and new narratives were constructed. This relates to Duncan's second ritual of art museums - the performance of visitors in the 'script or 'scenario' shaped by the arrangement of museums' settings (Duncan 1995, p. 20). This is because visitors who might be 'others' within the societies they live, can experience themselves in the art on display. In this way, displays of art of the present as well as of art of the past can help a people or class situate itself in the present. This is especially important in Brazil as a significant regressive change has occurred in the last five years and current political divisions threaten the construction of these narratives and the plurality of representation across different media. As ritual spaces and sites of persuasion, art museums are central to the plurality of memories, but also to the plurality of futures.

Brazil is a polarised country, the divisions of which have been widened by the present political situation that saw the former president, Dilma Rousseff, replaced by Michel Temer in a parliamentary coup in 2016 (Santos and Guarnieri 2016). Temer's power is reliant on the backing of conservative and evangelical Members of Parliament (MPs) and their supporters. When he became president, Temer abolished the Ministry of Culture, before then reinstating it after protests against his decision. In addition, he closed the Ministries for Women, Racial Equality, Youth, and Human Rights as well as the Ministry for Science and Technology. Furthermore, his first Cabinet included no women or African-Brazilians (Bentes 2018; Santos and Guarnieri 2016). These moves symbolised a shift in politics away from constructions of 'community' that entailed a degree of inclusivity (or at least the illusion of it) and some increases in rights for marginalised groups in society, to a more exclusionary version of society in which the powerful want to control the representation of the community and shape a representation that is less open to plural identities. As the power and influence of the conservatives continues to grow, the importance of alternative narratives as well as alternative memories increases significantly. Art museums provide an arena for both. Therefore, it is unsurprising that the conservative politicians would target cultural production because of its history of fighting for and fostering a more plural, permissive society. This is in addition to cultural production's history of a culture of memory concerning the dictatorship and of deceiving the regime's censors during that era. Owing to this, it was almost inevitable that these people and their supporters would target the spaces in which this culture is displayed.

In Brazil in 2017, the role of art museums as sites of persuasion grew further as the conservatives chose them as battlegrounds to enhance their agenda. In one example, conservative congressman Magno Malta threatened to sue the artist Antonio Oba for blasphemy and called him a 'piece of shit' and a 'son of a bitch' in a nationally televised senate hearing (Artnet News 2017). Oba's piece of art was a video installation 'Acts of Transfiguration: Disappearance of a Recipe for a Saint' (2015), in which he grinds a white statuette of the Virgin Mary into powder and then puts it over his body. The artist linked the piece to the Catholic Church's role in racism and poverty. On 19 September 2017, conservative protesters waited with rocks outside an art venue where Oba was scheduled to install his work for an exhibition associated with an important art prize. He then left Brazil owing to the number of death threats he received (Artnet News 2017).

In addition to Oba's case, from September to October 2017 a number of other high profile cases occurred. On 10 September, Santander Cultural, a museum in the city of Porto Alegre, closed its exhibition 'Queermuseum: Cartographies of Difference in Brazilian Art' early, after pressure from conservative groups and protests from conservative activists outside the museum. There were also protests outside some branches of Santander banks that resulted in windows being smashed. A Parliamentary Investigative Commission was then launched into the curator of the exhibition, Gaudêncio Fidelis. He was ordered to appear before the Senate for 'mistreatment of children and teenagers'. In October, violent protests took place over two days at the Museum of Modern Art, Sao Paulo, after a four-year-old girl touched the hand and foot of the naked artist Wagner Schwartz who was performing his piece La Bete (2017). Conservative protesters physically and verbally attacked museum employees and visitors and argued that the performance 'incites paedophilia'. 
The conservative Mayor of Sao Paulo, Joao Doria, accused the artist of 'paedophilia' and threatened to cut the museum's funding. Schwartz cancelled his performances and, similar to Oba, left the country. On 20 October, an exhibition entitled 'Histories of Sexuality' opened at the Museum of Art of Sao Paulo with entrance restricted to over 18 s only. This restriction was a reaction to pressure from conservative groups and local authorities. A counter protest by artists, including the globally renowned Chinese artist Ai Weiwei, led to minors being permitted with adult companions (Artnet News 2017; ArtReview 2017a, 2017b; Frieze 2017b, 2017c; MAM 2017).

An open letter signed by artists and curators exemplified the reaction among the counter protesters to the conservative protests against the Histories of Sexuality exhibition. It included the following paragraph:

We believe, however, that it is necessary to identify the focus of these attacks on civil liberties. It became evident that right-wing militants, sects from within neo-Pentecostal churches, certain politicians with great public responsibility—but lacking republican spirit-, civil servants and bureaucrats in the judiciary sphere, the police force and public prosecutors are joining forces against artistic creations and art institutions. They are censoring exhibitions, harassing visitors and museum employees and using social networks to demean and outrage people they disagree with. (ArtReview 2017b)

These examples have similarities with events in other international settings. For example, in the US there were calls for children to be excluded from the Chicago Art Institute's 1913 Armory show because paintings of nudes were on display. The Chicago Tribune newspaper complained the nudes could ' ... incite feelings of disgust and aversion' (Harris 1995, p. 1104). It also has parallels with the criminal prosecution in 1990 of the Director of the Cincinnati Contemporary Arts Center, Dennis Barrie (later acquitted at trial), for 'pandering obscenity' for putting on the controversial 'The Perfect Moment' exhibition by the artist Robert Mapplethorpe that included images of sadomasochistic sex and also had pictures of child nudity, and the reaction from political and religious leaders in the US to Andres Serrano's 1987 'Piss Christ' photograph (Coffee 2008; Dubin 1992). Along with the Brazilian case study, the US examples show the 'fierce struggle and impassioned debate' concerning museums and the understanding that to control museums is a means to have power over the values, truths and representations of communities (Duncan 1995, pp. 8, 9).

The Brazilian examples demonstrate how art museums, as sites of persuasion and secular ritual spaces in a polarised society, are currently battlegrounds in the country over who controls the representation of the Brazilian population and their values and truths. People from the different sides of Brazil's society understand the meaning and power of culture and the significance of locations in which this culture is exhibited. For instance, while the protests and counter protests about the Queermuseum exhibition concerned LGBTQ+ rights, they were also about Brazilian society in general and the extent to which different people want to be, and can be, inclusive and included. Dubin (2006, p. 479) argues that nearly every battle in culture wars has been ignited by works of art by those previously seen as outsiders and this is why these battles are about class and status. It is also worth being explicit about 'race' and ethnicity, because African-Brazilians have a long history of being 'outsiders' in Brazilian society (Sepulveda dos Santos 2005). For example, according to the art gallery where he is a featured artist, Oba's work 'encourages an investigation on the relationships of influence and interchange in the construction of Brazilian culture, the erasing of the black element of the history of Brazilian art that, nonetheless, gives room to an act of resistance and reflection on the idea of a national identity' (Mendes Wood DM 2018). Again, this relates to Duncan (1995) second ritual feature, because his art can concern the performance of the visitors in art museums, especially how the art museums can shape this performance by the configuration of their settings. The protests concerning the Queermuseum exhibition and Oba's work are examples that support Dubin's point about 'outsiders'. Bentes (2018, p. 59) affirms this point for Brazil and emphasises how it is these 'outsiders' who suffer from conservative politics. She highlights that they take important positions of resistance against the conservative shift and suffer severe repression. 
In the Americas, from pre-Columbian times to the present, there are many examples that illustrate, in a similar way to the Brazilian case study, how politicians understand the power and meaning of art and the locations in which it is displayed. For instance, in the 1970s, the US State Department secretly funded foreign exhibitions of Abstract Expressionist art to show intellectuals in Europe that freedom was thriving and was respected in the US (Duncan 1993). At the same time, US government policy banned the United States Information Agency from putting on exhibitions that included art by people viewed as sympathetic to communism, such as Picasso (Harris 1995). After 9/11, the USA Patriot Act in 2001 resulted in exhibitions closing and self-censorship measures in the US art world (Sholette 2010). Another example is the production from 1920-1950 of murals in Mexico after the country's Civil war, in places such as courts, government offices, museums and universities. These murals included work by 'the three great ones', Jose Clemente Orozco, Diego Rivera and David Alfaro Siqueiros. Many of the murals aimed to create a national identity in which the working class, peasant farmers and indigenous people were represented (Campbell 2003). Currently, in Brazil the opposite appears to be the aim of the conservatives. While the Mexican murals were and still are very public scripts to remind Mexicans who and what constitutes the Mexican identity, in Brazil the conservatives do not want this conversation and choose to discourage or limit broad representations of Brazilian identity. By encouraging violent protests at art museums as a method, they have chosen an aggressive approach and one that shares more similarities with actions in the US after the USA Patriot Act, than the soft power approach often employed by states in other settings (Nisbett 2016; Sylvester 2009).

In the Brazilian case study, the threats, protests and counter protests that took place posed different challenges to the usual threats such as damage (intentional and unintentional), theft and forgery often faced by art museums (Kerr 2015). For example, staff and visitors at the Museum of Modern Art, Sao Paulo, were physically and verbally attacked. Although intentional damage is commonly a large threat in art museums (Kerr 2015), the risk posed by the violent protests and the atmosphere of anger and incitement, resulted in the security challenges being very wide ranging in the Brazilian art museums as the threats were against the art, the art museum, the art museums' employees, the artists and visitors. Security challenges posed by the protests will be considered further in Section 5 . The involvement of politicians also helped to incite and generate a sense of approval concerning the actions and the threatened actions of the protesters.

In contrast, in the next case study, the violent protests were directed at politicians and a government.

\subsection{UK Case Study}

The UK case study concerns the Women's Social and Political Union's (WSPU) targeting of national and regional art museums as sites of violent protest in 1913/1914 in their fight for women's enfranchisement. Examples included art being attacked at the Birmingham Museum and Art Gallery in 1913, Manchester Art Gallery in 1913, National Portrait Gallery in 1914 and the National Gallery in March and May 1914. These violent protests formed part of a wider campaign described by the Suffragette, Sylvia Pankhurst:

The destruction wrought in the seven months of 1914 before the War excelled that of the previous year. Three scotch castles were destroyed by fire on a single night. The Carnegie Library in Birmingham was burnt. The Rokeby Venus, falsely, as I consider, attributed to Velazquez, and purchased for the National Gallery at a cost of $£ 45,000$, was mutilated by Mary Richardson. Romney's Master Thornhill, in the Birmingham Art Gallery, was slashed by Bertha Ryland, daughter of an early Suffragist. Carlyle's portrait of Millais [sic] in the National Gallery, and numbers of other pictures were attacked, a Bartolozzi drawing in the Dore Gallery being completely ruined. Many large empty houses in all parts of the country were set on fire ... Railway stations, piers, sports pavilions, haystacks were set on fire. Attempts were made to blow up reservoirs ... One hundred and forty one acts of destruction were chronicled in the Press during the first seven months of 1914'. (Pankhurst 1931, p. 544) 
The impact of the campaign against art museums was significant. Measures were put into place such as a watch list of 'known militant suffragettes' that was distributed to police and art museum attendants, and police and plain clothes detectives operated in the National Gallery from 1913 (Macleod 2006, p. 45). Following the Rokeby Venus attack, the National Gallery, the National Portrait Gallery, the Wallace Collection, the Guildhall Art Gallery, Hampton Court and the collections at Windsor Castle were all temporarily closed (Nead 1992).

Although the Suffragettes protested violently at many other locations, their choice of art museums illustrated their understanding of the symbolic power and meaning of the objects within the art museums. It also showed that the Suffragettes recognised art museums as symbolic cultural sites with the potential to be ideological, political and social instruments. In 1913/4, art museums were locations of high profile culturally and financially valuable art. Much of this art reinforced the patriarchal view of femininity and women's roles in society (Berger 1972; Duncan 1995; Macleod 2006). Particular paintings such as the Rokeby Venus at the National Gallery were prime examples. While the attack on the Rokeby Venus in 1914 had the wider more symbolic aim of violently protesting against the patriarchal ideal and projecting a very public rejection of it (Nead 1992), it also had the more specific purpose of protesting against the rearrest of Emmeline Pankhurst who was hunger striking in Holloway Prison (Macleod 2006). Mary Richardson, who attacked the painting and slashed it with a 'chopper', said: 'I have tried to destroy the picture of the most beautiful woman in mythological history as a protest against the Government ....' (Cordes and Turcan 1993, p. 99). As well as the choice of the specific painting as a target, the location was also important as the National Gallery was a national symbol of the prevailing governing values that the Suffragettes rejected and a location that reinforced an universalisation of these particular values (Macleod 2006, p. 54). Speaking about the violent protest at the Manchester Art Gallery in 1913 that involved an attack on 13 paintings by Suffragettes Lilian Forrester, Annie Briggs, Evelyn Manesta, the Suffragette Ethel Smith justified the attack with a powerful statement that also rejected the universalisations of these values:

There is to me something hateful, sinister, sickening in this heaping up of art treasures, this sentimentalising over the beautiful, while the desecration and ruin of bodies of women and little children by lust, disease, and poverty are looked upon with indifference. (Manchester Art Gallery 2017)

Macleod (2006) highlights the role of art museums as sites of persuasion and argues that Richardson's protest at the National Gallery was an example of culture wars. Importantly, the Suffragettes were fully aware of how their 'performance' within this type of ritual space could shape the 'script' or 'scenario' within the art museums (Duncan 1995, p. 20), or, more accurately, rip up the script, and, therefore, the effect it might have on the media, government and public. In their coverage, the media portrayed the painting as the 'ideal victim' and labelled Richardson as 'Slasher Mary', 'the Ripper', 'the Slasher' as if she had murdered an actual woman (Gamboni 1997; Nead 1992). In their framing of the event and the language used to describe Richardson, the media actually accentuated the point that Richardson, Smith and other Suffragettes were trying to make against patriarchal culture and its imposition of how females should act and be viewed within society (Nead 1992).

The fact that art museums became 'battlegrounds' and 'sites of persuasion' for the Suffragettes has clear similarities with the Brazilian case study in 2017 (Hunter 1991; Macleod 2006; Sepulveda dos Santos 2003). However, in contrast to the protests in Brazil that aimed to impose more conservative, moralistic ideals on society, the Suffragettes wanted to create a more equal, open, progressive society. In addition, they were also acting at a time when art museums were less open to being sites of persuasion, but rather were sites where the patriarchal ideal and the interests of the powerful were often being reaffirmed (Berger 1972; Duncan 1995; Macleod 2006). 


\section{Implications for Crime Prevention}

The two case studies illustrate why and how art museums have been sites of violent protest and why they will be in the future. They also highlight the levels and types of threat to art museums. A critical issue is how art museums can be protected so that violent protests, whether they are for a legitimate cause or not, can be managed successfully or be avoided altogether. This is important to prevent danger to people, the art on display and the art museums.

Previous academic work on art and heritage crime has made use of environmental criminologies such as situational crime prevention (SCP) (Grove and Pease 2014; Kerr 2015). Useful SCP recommendations have been proposed for heritage crime by Grove and Pease (2014, pp. 109-11). Adapted from Cornish and Clarke's 25 techniques of SCP (Cornish and Clarke 2003), Grove and Pease's logical SCP techniques include good ideas for preventing many types of heritage crime (Grove and Pease 2014). These techniques are useful for art museums. Importantly, Grove and Pease's work highlights the special challenges that heritage crime can present (Grove and Pease 2014). Although protests are not explicitly mentioned, three points within their approaches of the $25 \mathrm{SCP}$ techniques for heritage crime are particularly relevant for protests. First, in technique 4 (Deflect Offenders) the approach 'Provide designated spaces for disruptive activities' has use for some peaceful protests as it can enable a location to incorporate the protests and provide a space for the 'discussion' even if it is contentious. Second, technique 19 (Neutralise Peer Pressure) has the approach 'Organise events for local community, engaging with disenfranchised groups' which can help potential local protesters understand the space and engage with it. Third, in technique 10 (Strengthen formal surveillance) the approach 'Maximise staffing at times of greatest risk' is a logical option owing to the threats posed by protests, especially violent protests (Grove and Pease 2014, pp. 109-11). A crucial point to raise, though, is whether art museums understand sufficiently when they are at great risk from the panoply of threats that they can face and whether they can react quickly enough to these threats when they do become aware.

As this article has shown, the current threat to art museums in Brazil from violent protests is large as they are important battlegrounds within the wider culture wars that are taking place in the country. These protests and the counter protests look set to continue, and they will pose large problems for art museums. The challenge is increased by the fact that leading politicians are encouraging violent protests. It is important for art museums' management and those leading security to be aware of the security threats posed and to be conscious that these threats must be fully considered alongside the usual threats such as damage (intentional and unintentional), theft and forgery. The ingenuities of protest add to the complexity in dealing with the potential threats. Examples include the use of social media platforms to spread misinformation about exhibitions, the use of social media and anonymous phone calls in the threats, and people waiting outside of locations to attack artists rather than targeting them within the space (where there is security). In many ways, the nature of the threats takes some of the response out of the scope of museum security. For example, during the protests at the Museum of Modern Art, Sao Paulo, the local police force (the Guarda Civil Municipal) were the people trying to control the protests (MAM 2017; Artnet News 2017).

Art museums responded in very different ways to the violent protests in 2017. The Museum of Modern Art, Sao Paulo, issued a statement after the violent protests. The museum made clear that the threats were against people and property, repudiated the attacks and justified its right to show art that dealt with 'sensitive issues'. It also explained that there had been signs making people aware of the nature of Schwartz's interactive installation. Moreover, in the hope of preventing further protests, it tried to correct the misinformation about the installation (MAM 2017). While the Museum of Modern Art, Sao Paulo, justified its stance and did not self-censor, self-censorship was the choice at other art museums. This was evidenced by the early closure of the Queermuseum exhibition at the Santander Cultural Museum in Porto Alegre (despite Santander having been involved in the planning of the exhibition and aware about all of the art) and the age restrictions at the Histories of Sexuality exhibition at the Museum of Art of Sao Paulo (ArtReview 2017a, 2017b). These cases of 
self-censorship demonstrate the impact of the threats to cut funding to museums by conservative politicians opposed to specific exhibitions and corporate sponsors afraid of negative publicity. However, even if self-censorship were to become an unfortunate common choice of response for art museums and their sponsors, the artistic activities during the 1964-1985 dictatorship of people such as Artur Barrio, Antonio Manuel, and Cildo Meireles show how artists can subvert spaces within art museums and that self-censorship by art museums can encourage protests by artists and their supporters (Calirman 2012). Therefore, protests could still occur, but the protagonists would be different and the protests potentially more creative and less violent (Calirman 2012).

In the UK, art museums are potential targets for violent and non-violent protests with an array of different motivations. Examples include protests against corporate sponsorship of exhibitions and protests by groups such as the UK based fathers' rights campaign group Fathers for Justice (Art Not Oil 2016; Chong 2013; Liberate 2015). Museums have shown that they can respond to some of these threats, especially if it is the space that is targeted rather than a specific art object. However, there is controversy about some of the methods employed. For example, when dealing with peaceful acts by activists protesting against the oil and gas company BP's sponsorship of cultural locations, on site security teams collaborated with BP's security team and, allegedly, BP or a security consultant even infiltrated protest groups to gather information about their activity. While this raises obvious ethical questions, it does show how some peaceful protests have been managed and that art museums are responding to some peaceful protests (Art Not Oil 2016). It is worth noting, though, that perhaps the most 'managed' response was driven by a private company seeking 'a social licence to operate' (Art Not Oil 2016, p. 3). Despite responses to peaceful protest, the main concern for this article is the response to the threat of violent protest.

The largest threat in the UK potentially comes from people linked to terrorist groups such as ISIS and it is when faced by this specific threat in 2017 that some art museums were slow to react in employing certain security strategies. People who work in the securitization and policing of art crime, including the Head of Security at a major art museum in London, have warned that iconoclasm and 'theft by destruction' is a large risk and have highlighted terrorism as a 'major concern' in the UK (Hill 2008; Kerr 2015, 2018). The recent conviction of Safaa Boular, who planned an attack on the British museum, further supports this assertion (BBC 2018). Writing prior to the 2012 London Olympics, Coaffee et al. (Coaffee et al. 2011, p. 3323) argued that: 'London is uniquely prepared to counter the threat of terrorism given decades of experience of developing physical, managerial and technological systems to defend particular spaces from terror attacks.' Despite this preparedness to defend many spaces effectively, some cultural locations in London such as specific art museums appeared to be inadequately prepared in the face of the threat of violent protest posed by terrorists in 2017.

Between March and June 2017, the UK experienced four violent incidents that were labelled as terrorist attacks: one in Manchester, three in London. The target in Manchester on 22 May 2017 was a pop concert and the three targets in London were a political/tourist site (Westminster) on 22 March 2017, a popular Night Time Economy area (Borough) on 3 June 2017 and a place of worship (a mosque in Finsbury Park) on 19 June 2017. These locations demonstrate the variety of targets that currently exist for perpetrators of such attacks. In March 2017, some art museums in London responded quickly to the raised threat level after the Westminster attack. For example, one large national art museum implemented significant security changes concerning its entrances and introduced thorough bag checks (Fieldwork 21, 28 March 2017). In contrast, after the Westminster attack, simple measures such as bag checks and reduced entry points were not in place at some art museums in London, including at two of the largest art museums (Fieldwork 28 March 2017). When bag checks were introduced at two large art museums after the Borough attack, they were far from extensive and took place in the entrances of the building and not a short distance away (which would have provided an extra layer of security for the building and those inside). There was, though, a reduction of entry points and their security personnel were made to be more visible through wearing high visibility vests (Fieldwork 3 July 2017, 16 July 2017). Although there are concerns about the logistical challenges of bag 
checks (Kerr 2015), the checks and reduced entry points could have been in place earlier and added further potential obstacles to a possible attacker. For example, in 2010 a terrorist threat led to temporary bag checks at the main entrances at a national museum in London (Kerr 2015). The same museum already had bag checks in place in 2017 before the terrorist attacks that occurred between March and June 2017. Even after the attack in Finsbury Park, the third attack on London in four months, one large national art museum still continued not to have bag checks on all doors (Fieldwork 4 July 2017).

The slow response at some large art museums in 2017 is in contrast with the reaction to the threat of violent protest posed by the Suffragettes in 1913/4. Awareness of the seriousness of the threat in 1913/4 was shown by the significant security measures such as closing important art museums and restrictions on items that people could bring into other galleries (such as muffs, wrist-bags and sticks) and the distinctly inappropriate restriction of the entrance of females unaccompanied by a man or without a letter of recommendation from one. These were in addition to the 'watch list' of 'known militant suffragettes', the use of police and plain clothes detectives in the National Gallery from early 1913 before it was temporarily closed in 1914 and the extreme measure of closing art museums (Macleod 2006). The difference in scale in the reaction between 1913/4 and 2017 could be attributed to the fact that the Suffragettes were clearly targeting cultural locations (with art museums as prime targets), while in 2017 art museums were potential targets rather than actual confirmed targets. We are aware now, though, that at least one of the museums was an actual target (BBC 2018).

The slow reaction to attacks at specific art museums in 2017 is a large concern as it occurred despite many of these locations monitoring the threats from terrorism, being well prepared for other security threats such as thefts, sharing information about threats through networks such as the National Museum Security Group, some of their personnel receiving training in 'Counter-Terrorism' (hosted by BP for personnel from art museums that it sponsored), and the fact the Department for Digital, Culture, Media and Sport has recommended that art museums with national collections should have the highest level of protection (Art Not Oil 2016; Kerr 2015; Sylvester 2009). An important reason for this slow reaction could be the lack of focus on 'meaning' in 2017 when addressing crime threats. Proponents of SCP are clear that in aiming to reduce opportunities for crime, their focus is on situational and environmental factors and on trying to answer the question 'how?' rather than 'why?' before then changing or removing the factors in the 'how'. For example, at the start of their book 'Outsmarting the Terrorists', which aims to use SCP techniques to remove opportunities for terrorism, Clarke and Newman (2006) state clearly: 'In fact, we see it as an important strength of our approach that we do not get bogged down in the source of motivations. We are much more interested in learning about how terrorism is committed than why. Understanding how it is done helps us better know how to intervene' (Clarke and Newman 2006, p. Viii). This focus is in line with long-term shifts within criminology and the significant influence over it by the crime control industry. Hayward and Young (2004) have warned that this leaves a criminology that 'does not demand debates as to the very nature of these battles' (Hayward and Young 2004, p. 262).

$\mathrm{SCP}^{\prime}$ s focus on reducing crime has practical merits for combatting incidences of specific crimes in art museums such as particular types of theft but SCP is limited when faced by some other threats. For example, when considering opportunities for art theft, acronyms CRAVED (concealable, removable, available, valuable, enjoyable, disposable) and VIVA (Value, Inertia (weight of the object), Visibility, and Access) are useful for assessing some suitable targets (Clarke and Newman 2006; Cornish and Clarke 1986; Kerr 2015). However, violent protests are an example of actions that arguably support the many criticisms of SCP, primarily the critique that it focuses too much on the 'how', disregarding the 'why'. Some debates between proponents and critics of SCP have been antagonistic and sometimes personal in nature (see Farrell (2010) versus Hayward (2007)). However, what can be lost in analyses of SCP is the acceptance that despite the larger 'causes of crime' not being the focus, the 'little whys' can be sought (Freilich and Newman 2017). Although those managing art museums can use their institutions to enable people to highlight, expose and create conversations and debates about societies' wider issues such as inequalities and injustices, those managing the security 
cannot be expected to address in depth the larger 'whys' concerning political violence. However, despite this, it helps crime prevention methods in art museums if there is awareness among those managing security of the source of motivations of the 'larger whys' as this can feed into the 'little whys'. This awareness need not lead to Clarke and Newman's concern about 'getting bogged down in the source of the motivations' (Clarke and Newman 2006, p. Viii). However, some potential targets can be missed or reactions too slow if there is a lack of engagement with the source of motivations. Clarke and Newman (2006) wrote that:

We have had to guess at many of the choices that the terrorists must make in planning and succeeding in their task. But these guesses are reasoned ones, based on the assumption that the terrorists must plan their work and make logical choices if they are to be successful. (Clarke and Newman 2006, p. 63)

Despite being global targets, cultural locations such as art museums were notable omissions from their 'reasoned guesses' in Outsmarting the Terrorist and were absent from the book.

Whether the violent protests are related to political violence or other reasons, SCP measures must take into more consideration the meaning that art museums and the art on display can have for people as sites of persuasion. This is not to say that in some cases this is not happening, indeed the limited empirical research undertaken for this article showed that some art museums were aware of the threat in 2017 and had responded quickly. However, the fact that some other specific large national art museums in London reacted very slowly in 2017 in implementing some basic SCP measures is worrying. Owing to this concern, this author argues that more emphasis could be placed on the past and present meaning that an art museum has or could have for different people, and, in doing so, engender more awareness of diverse potential threats to art museums and, therefore, help in looking for the 'little whys'. This would assist with assessing the dangers to the art, the employees, visitors and the art museum itself, and could prevent a slow response to a potential threat. This awareness could come before consideration of the 25 techniques of SCP and then help shape the approaches within them. For instance, although art theft has been used as a form of protest (Kerr 2018), the threat of theft is usually very different from violent protest. When faced by the threat of violent protest, specific art or types of art might require more protection and this art should be a prime focus in security concerns. The Suffragettes' specific targeting of the Rokeby Venus is an example. There also needs to be an awareness of the danger to artists if they themselves are part of the display, as was the case with the protests in Brazil in 2017. In addition, the space within the art museum becomes more important when considering violent protest rather than peaceful protest. In line with art museums being ritual spaces (Duncan 1995) and Hayward's argument that space needs to be approached as 'a complex constellation of social and power relations' (Hayward 2012, p. 459), these spaces need to be considered for the meaning or symbolic significance that they can have for people. Art museums can try to manage and/or incorporate peaceful protest if it is appropriate to do so. With violent protest, this is obviously much more difficult owing to the nature of the protest. Whether protest is included in the art museum or excluded, an awareness of the increased threat to museum staff and visitors must be present in order to shape how crime prevention measures can be applied. When this awareness exists, the ingenuities of protest must also be factored in. This is especially the case if there is the threat of violence. It is important, though, that these measures should be appropriate because measures such as self-censorship of exhibitions, as happened in Brazil in 2017, is not an appropriate answer. Similarly, extreme exclusionary preventive measures such as those employed in 1913/1914 in the UK, which saw women banned from entering art museums without an accompanying male or a recommendation letter from a man, should not be implemented. In light of the fact that late modern surveillance techniques, based often on anticipatory justice and exclusionary strategies, can be controversial, it is worth making this point in 2018 (Castells 2002).

Grove and Pease (2014) state that the approaches for the 25 techniques can be linked to the imaginations of those analysing and implementing security on the site. This encourages those doing the analysis to understand the meaning and symbolism that a location can have. To assist in analysing 
the attractiveness of potential targets, the acronym EVIL DONE (Exposed, Vital, Iconic, Legitimate, Destructible, Occupied, Near and Easy) can also help (Clarke and Newman 2006, p. 15). Although not designed for art museums, it has use for art museums in many countries concerning terrorism. Art museums, especially national art museums, include many combinations of the EVIL DONE words, and these words can relate to the meaning and representation of an art museum. Furthermore, the acronym has use for other violent protests that might not be termed as 'terrorism'. For instance, the Brazilian art museums targeted by violent protests in 2017 also have combinations of the words. An EVIL DONE assessment conducted by arts museums' management and their security can aid in making 'reasoned guesses' (Clarke and Newman 2006, p. 63) more reasoned. This could help art museums be more proactive rather than reactive to the threats posed by violent protest. Ideally, this author would like art museums to be very aware of the politics that directly and indirectly affect them and their art objects, and would prefer a deeper analysis and awareness of the meaning that art museums can have for the many people who wish to target them in order for this to feed into SCP techniques and their related approaches. However, in the absence of the above, EVIL DONE is a pragmatic option as it is a useful basic analytical tool that can push people into thinking imaginatively about the meaning of art museums when considering potential threats and therefore respond quicker.

\section{Conclusions}

Globally, art museums and the objects within them have a history of being attacked and of being used as stages on which to perform violent protest. There needs to be more awareness and understanding of why they might be targets, the performance of protest and the violence that they can entail. When this awareness exists, responses need to be quick. As shown in Brazil in 2017, this awareness also relates to when governing politicians and their supporters encourage and enact the violence. In addition, more understanding of the source of the motivation can help to decide whether the protest can be managed or should be prevented and/or guarded against. It can also help shape the approaches within SCP techniques. For example, if an art museum is open to be a site of contestation then some protests can take place peacefully within the museum space and become part of the performance of the ritual space. However, this incorporation becomes more difficult if it is the state itself that is trying to impose rather than explore identities and values, and if it is governing politicians who are encouraging people to violently protest in the art museums, as is currently the case in Brazil. Furthermore, if the violent protest comes from supporters of groups and people that aim to destroy, then substantial SCP measures are the most appropriate.

As ritual spaces, the performances of the protests are crucial and can shape the outcome of protesters' campaigns. For example, although art works and art museums were victims of the Suffragettes in their campaign for enfranchisement, the violent actions in the art museums played a role in advancing democracy. Macleod (2006) argues:

... the art museum is also implicated in the creation of a politicized mass public and it remains fascinating to consider how museums have acted not simply as sites for protest, but how they have contributed to the creation of a civil society where political debate, and occasionally agitation, is a necessary part of the progress of democracy. (Macleod 2006, p. 55)

The fact that art museums are battlegrounds for culture wars highlight their importance in societies. They are not just places, they are spaces in which the present and future can be shaped, and locations in which representations of community and society can be disputed and contested. This can happen for positive reasons such as women's enfranchisement in the UK or negative reasons such as the current attempts in Brazil to create a more conservative, exclusive society. More understanding about how they can be battlegrounds can help with SCP techniques and their approaches. The fact that these approaches 'are limited only by one's imagination' (Grove and Pease 2014, p. 108) and can relate to the 'meaning' of the art museum show that there is space for the criminological imagination to be employed in SCP, especially when faced with ingenuities of 
violent protest. An encouragement of this understanding could lead to changes in how SCP is viewed within crime science and criminology, and, more specifically, how it is employed within art museums and other settings.

Funding: This research received no external funding.

Acknowledgments: I would like to thank the reviewers for their very useful comments and suggestions.

Conflicts of Interest: The author declares no conflict of interest.

\section{References}

Abungu, George. 2016. Illicit Trafficking and Destruction of Cultural Property in Africa: A Continent at a Crossroads. In Art Crime Terrorists, Tomb Raiders, Forgers and Thieves. Edited by Noah Charney. Basingstoke: Palgrave Macmillan.

Art Newspaper. 2017. Art's Most Popular: Exhibition and Museum Visitor Figures 2017. Available online: https:/ /www.theartnewspaper.com/news/art-s-most-popular-exhibition-and-museum-figures-2017 (accessed on 24 June 2018).

Art Not Oil. 2016. BP's Cultural Sponsorship: A Corrupting Influence. May 3. Available online: http://www.artnotoil.org.uk/sites/default/files/BPs\%20Corrupting\%20Influence.pdf.pdf (accessed on 22 June 2018).

Artnet News. 2017. Death Threats, Intimidation, Censorship: Inside the Far Right's Assault on Brazil's Art Scene. Available online: https://news.artnet.com/art-world/artistic-freedom-censorship-brazil-1157357 (accessed on 11 December 2017).

ArtReview. 2017a. Brazilian Museum Closes Queer Art Show After Protests. Available online: https:// artreview.com/news/news_11_september_17_brazilian_museum_closes_queer_art_show_after_protests/ (accessed on 11 December 2017).

ArtReview. 2017b. Brazilian Artists Mount Fight Against Censorship. Available online: https: //artreview.com/news/news_20_october_2017_brazilian_artists_mount_fight_against_censorship / (accessed on 11 December 2017).

Barrett, Jennifer. 2011. Museums and the Public Sphere. Chichester: Wiley-Blackwell.

BBC. 2018. 'London teen guilty of museum terror plot'. Available online: https://www.bbc.co.uk/news/uk44359751 (accessed on 5 June 2018).

Becker, Howard. 1982. Art Worlds. Berkeley: University of California Press.

Bentes, Ivana. 2018. The Impeachment was a Fascist and Conservative Turn against Culture. Journal of Latin American Cultural Studies 27: 43-61. [CrossRef]

Berger, John. 1972. Ways of Seeing. London: Penguin Books.

Bessette, Anne. 2016. Vandalism in Art Museums: Case Studies from 1985 to 2013. Journal Art Crime 15.

Bourdieu, Pierre. 1996. The Rules of Art: Genesis and Structure of the Literary Field. Translated by Emanuel Susan. Stanford: Stanford University Press. First published 1992.

Bourdieu, Pierre, and Alain Darbel. 1969. L' Amour de L'Art. Lês Musées d'Art Européen et Leur Public. Paris: De Minuit.

Brodie, Neil. 2015. Syria and its Regional Neighbors: A Case of Cultural Property Protection Policy Failure? International Journal of Cultural Property 22: 317-35. [CrossRef]

Burgess, Robert. 2000. In the Field: An Introduction to Social Research. London: Routledge.

Calirman, Claudia. 2012. Brazilian Art under Dictatorship: Antonio Manuel, Artur Barrio, and Cildo Meireles. Durham: Duke University Press.

Campbell, Bruce. 2003. Mexican Murals in Times of Crisis. Tucson: University of Arizona Press.

Castells, Manuel. 2002. The Castells Reader on Cities and Social Theory. Edited by Ida Susser. Oxford: Blackwell.

Chong, Derrick. 2013. Institutions Trust Institutions Critiques by Artists of the BP/Tate Partnership. Journal of Macromarketing 33. [CrossRef]

Clarke, Ronald, and Graeme Newman. 2006. Outsmarting the Terrorists. Westport: Praeger.

Coaffee, Jon, Pete Fussey, and Cerwyn Moore. 2011. Laminated Security for London 2012: Enhancing Security Infrastructures to Defend Mega Sporting Event. Urban Studies 48: 3311-27. [CrossRef] 
Coffee, Kevin. 2008. Cultural Inclusion, Exclusion and the Formative Roles of Museums. Museum Management and Curatorship 23: 261-79. [CrossRef]

Cordes, Christopher, and Maja Turcan. 1993. Art Vandalism. British Journal of Criminology 33: 95-102. [CrossRef] Cornish, Derek, and Ronald Clarke. 2003. Opportunities, Precipitators and Criminal Decisions: A Reply to Wortley's Critique of Situational Crime Prevention. Crime Prevention Studies 16: 41-96.

Cornish, Derek, and Ronald Clarke, eds. 1986. The Reasoning Criminal: Rational Choice Perspectives on Offending. New York: Springer.

Dubin, Steven. 1992. Arresting Images: Impolitic Art and Uncivil Actions. Abingdon: Routledge.

Dubin, Steven. 2006. Incivilities in Civil(ized) Places: 'Culture Wars' in Comparative Perspective. In A Companion to Museum Studies. Edited by Sharon MacDonald. Oxford: Blackwell.

Duncan, Carol. 1993. The Aesthetics of Power. Essays in the Critical History of Art. Cambridge: Cambridge University Press.

Duncan, Carol. 1995. Civilising Rituals Inside Public Art Museums. London: Routledge.

Farrell, Graham. 2010. Situational Crime Prevention and Its Discontents: Rational Choice and Harm Reduction versus 'Cultural Criminology'. Social Policy and Administration 44: 40-66. [CrossRef]

Francioni, Francesco, and Federico Lenzerini. 2006. The Obligation to Prevent and Avoid Destruction of Cultural Heritage: From Bamiyan to Iraq. In Art and Cultural Heritage: Law, Policy and Practice. Edited by Barbara Hoffman. New York: Cambridge University Press.

Freilich, Joshua, and Graeme Newman. 2017. Situational Crime Prevention. In Oxford Research Encyclopedia of Criminology. New York: Oxford University Press.

Frieze. 2017a. How Important is Art as a Form of Protest? Available online: https://frieze.com/article/howimportant-art-form-protest\#Jeremy\%20Deller (accessed on 23 March 2018).

Frieze. 2017b. Looking Back 2017: Judith and Holofernes in Brazil. Available online: https:/ / frieze.com/article/ looking-back-2017-judith-and-holofernes-brazil (accessed on 23 March 2018).

Frieze. 2017c. Censorship in Brazil: Five Responses. Available online: https:/ / frieze.com/article/censorshipbrazil-five-responses (accessed on 23 March 2018).

Gamboni, Dario. 1997. The Destruction of Art: Iconoclasm and Vandalism since the French Revolution. London: Reaktion Books.

Grove, Louise, and Ken Pease. 2014. A Situational Crime Approach to Heritage Crime Prevention. In Heritage Crime. Progress, Prospects and Prevention. Edited by Louise Grove and Suzie Thomas. Basingstoke: Palgrave Macmillan.

Harris, Neil. 1995. Museums and Controversy: Some Introductory Reflections. The Journal of American History 82: 1102-10. [CrossRef]

Hayward, Keith. 2007. Situational Crime Prevention and its Discontents: Rational Choice Theory versus the 'Culture of Now'. Social Policy \& Administration 41: 232-50.

Hayward, Keith. 2012. Five Spaces of Cultural Criminology. British Journal of Criminology 52: 441-62. [CrossRef]

Hayward, Keith, and Jock Young. 2004. Cultural Criminology: Some Notes on the Script. Theoretical Criminology 8: 259-85. [CrossRef]

Hill, Charles. 2008. Art crime and the Wealth of Nations. Journal of Financial Crime 15: 444-448. [CrossRef]

Hunter, James Davison. 1991. Culture Wars: The Struggle to Define America. New York: Basic Books.

Kerr, John. 2014. The Art of Risk Management: The Crucial Role of the Global Art Insurance Industry in Enabling Risk and Security. Journal of Risk Research 19: 331-46. [CrossRef]

Kerr, John. 2015. The Securitization and Policing of Art Theft: The Case of London. Farnham: Ashgate/Routledge.

Kerr, John. 2018. Taking Culture and the Balancing Act of Power. In Handbook on Art Crime. Edited by Duncan Chappell and Saskia Hufnagel. London: Palgrave Macmillan.

Liberate, Tate. 2015. Confronting the Institution in Performance. Performance Research 20: 78-84.

Macleod, Suzanne. 2006. Civil Disobedience and Political Agitation: The Art Museum as a site of Protest in the Early Twentieth Century. Museum and Society 5: 44-57.

MAM. 2017. Museum of Modern Art, Sao Paulo. Available online: http://mam.org.br/2017/09/29/nota-deesclarecimento/ (accessed on 10 July 2018).

Manchester Art Gallery. 2017. Available online: http:/ / manchesterartgallery.org/blog/manchester-art-galleryoutrage/ (accessed on 10 April 2017). 
Mendes Wood DM. 2018. Antonio Oba Biography. Available online: http://www.mendeswooddm.com/en/ exhibition/antonio-oba (accessed on 18 April 2018).

Nead, Lynda. 1992. The Female Nude, Art, Obscenity and Sexuality. Abingdon: Routledge.

Newman, Graham, and Ronald Clarke. 2007. The Situational Prevention of Terrorism: Some Ethical Considerations. Criminal Justice Ethics 2007: 65-66. [CrossRef]

Nisbett, Melissa. 2016. Who Holds the Power in Soft Power? Arts E International Affairs. [CrossRef]

Pankhurst, Sylvia. 1931. The Suffragette Movement-An Intimate Account of Persons and Ideals. London: Longmans, Green \& Co.

Pelegrini, Sandra. 2015. Authoritarianism Versus Freedom of Expression: Brazilian Theater Dribbles Past Censorhip with Insight. Antitesis 8: 67-90. [CrossRef]

Ranciere, Jacques. 2010. Dissensus: On Politics and Aesthetics. Steven Corcoran, trans. and ed. London: Continuum International Publishing Group.

Rutelli, Francesco. 2016. The Return of Iconoclasm: Barbarian Ideology and Destruction by ISIS as a Challenge for Modern Culture, Not Only for Islam. In Art Crime Terrorists, Tomb Raiders, Forgers and Thieves. Edited by Noah Charney. Basingstoke: Palgrave Macmillan.

Santos, Fabiano, and Fernando Guarnieri. 2016. From Protest to Parliamentary Coup: An Overview of Brazil's Recent History. Journal of Latin American Cultural Studies 25: 485-94. [CrossRef]

Schneider, Nina, and Rebecca Atencio. 2016. Reckoning with Dictatorship in Brazil: The Double-Edged Role of Artistic-Cultural Production. Latin American Perspectives 43: 12-28. [CrossRef]

Sepulveda dos Santos, Myrian. 2003. Museums and Memory: The Enchanted Modernity. Journal for Cultural Research 7: 27-46. [CrossRef]

Sepulveda dos Santos, Myrian. 2005. Representations of Black People in Brazilian Museums. Museum and Society 3: $51-65$.

Sholette, Gregory. 2010. Dark Matter: Art and Politics in the Age of Enterprise Culture. London and New York: Pluto. Soyinka, Wole. 2004. Climate of Fear. London: Profile Books.

Sylvester, Christine. 2009. Art/Museums. International Relations Where We Least Expect It. Boulder: Paradigm Publishers.

Taylor, Verta, and Nella Van Dyke. 2004. 'Get Up, Stand Up': Tactical Repertoires of Social Movements. In The Blackwell Companion to Social Movements. Edited by David Snow, Sarah Soule and Hanspeter Kriesi. Malden: Blackwell.

The Guerrilla Girls. 2018. Available online: www.guerrillagirls.com (accessed on 8 May 2018).

Tillmans, Wolfgang. 2017. Introduction to Everyone for Themselves: A discussion about Social Lives Tate Talk. London: Tate Modern.

UNESCO. 2017. UNESCO Director-General Condemns Destruction of the Tetrapylon and Severe Damage to the Theatre in Palmyra, a UNESCO World Heritage Site. Available online: http:/ / en.unesco.org/news/unescodirector-general-condemns-destruction-tetrapylon-and-severe-damage-theatre-palmyra (accessed on 7 August 2017).

Young, Jock. 2007. Vertigo of Late Modernity. London: Sage.

(C) 2018 by the author. Licensee MDPI, Basel, Switzerland. This article is an open access article distributed under the terms and conditions of the Creative Commons Attribution (CC BY) license (http://creativecommons.org/licenses/by/4.0/). 